\title{
CYTOTOXIC EFFECT OF SYNTHESIZED SILVER NANOPARTICLES BY PULSE LASER ABLATION ON BREAST CANCER CELL LINE (AMJ13) FROM IRAQI PATIENT AND NORMAL HUMAN LYMPHOCYTES
}

\author{
NAWFAL N R ALRAWI ${ }^{1}$, MOHAMMED Q AL-ANI ${ }^{2}$, NAHI Y YASEEN ${ }^{3}$ \\ ${ }^{1}$ The Ministry of Education, Directorate of Anbar Education, Iraq. ${ }^{2}$ Department of Biology, College of Science, University of Anbar, Anbar, \\ Iraq. ${ }^{3}$ Department of Oncology, Iraqi Centre for Cancer and Medical Genetics Research, Al-Mustansiriya University, Baghdad, Iraq. \\ Email: drmohammedqais1975@gmail.com \\ Received: 23 November 2017, Revised and Accepted: 05 January 2018
}

ABSTRACT

Objective: Synthesized silver nanoparticles (AgNPs) in liquids were investigated as anticancer cells in the present study. Cytotoxic activities of six different concentrations $0.78,1.56,3.125,6.25,12.5$, and $25 \mu \mathrm{g} / \mathrm{ml}$ of AgNPs against human breast cancer cell line (AMJ13) and lymphocytes were assessed with MTT assay.

Methods: A Q-Switched Nd: YAG pulsed laser $(\lambda=1064 \mathrm{~nm}, 800 \mathrm{~mJ} / \mathrm{pulse})$ was used for ablation of a pure silver plate to synthesis AgNPs in the polyvinylpyrrolidone and deionize distilled water. Ultraviolet-visible spectroscopy confirmed the synthesis of AgNPs and zeta potential was evaluated. Morphology and size were analyzed by transmission electron microscope. AgNPs concentrations were determined by atomic absorption spectroscopy. Possibilities of apoptosis induction were confirmed using mitochondrial membrane potential assay, DNA fragmentation assay, and glutathione (GSH) assay.

Results: The results indicated that AgNPs were able to induce an inhibition of AMJ13 cells compared their damaging effect toward normal lymphocytes were at minimal according to viability with MTT assay.. Furthermore, these results suggested that AgNPs-induced mitochondrial-mediated apoptosis cause DNA fragmentation, but no significant change in GSH level in AMJ13 cells.

Conclusions: The overall results indicated that the physically synthesized AgNPs were exhibited dose-dependent cell death in AMJ13 breast cancer cell line, while the effect of AgNPs on lymphocytes was very low, suggesting that physically synthesized AgNPs might be a potential alternative agent for human breast cancer therapy.

Keywords: Silver nanoparticles, Metal silver, AMJ13, Cytotoxicity, Lymphocytes, Mitochondrial transmembrane potential, DNA fragmentation, Glutathione.

(c) 2018 The Authors. Published by Innovare Academic Sciences Pvt Ltd. This is an open access article under the CC BY license (http://creativecommons. org/licenses/by/4. 0/) DOI: http://dx.doi.org/10.22159/ajpcr.2018.v11i4.23878

\section{INTRODUCTION}

Breast cancer is the second most common cause of cancer death in women [1,2]. Many cancers initially respond to chemotherapy, and later they develop resistance [3-5]. Currently available chemopreventives and chemotherapeutic agents cause undesirable side effects [6,7]; therefore, developing a biocompatible and effective method of treatment for cancer is necessary. The development of nanotechnology has been a grace to humankind as its significance paved the way for several applications in therapeutics [8]. Nanobiotechnology is the most promising field for generating new kinds of nanomaterials for biomedical applications [9]. Since nanoparticles (NPs) have the affinity to an acidic environment, which characterized tumor tissue, it is believed that selective targeting strategies with NPs facilitate more effective cancer detection and treatment with minimized side effects to normal cells [10]. Silver NPs (AgNPs) have gained much interest in the field of nanomedicine due to their unique properties and obvious therapeutic potential in treating a variety of diseases [11]. AgNPs are increasingly used in various fields, due to their unique physical and chemical properties, several applications include antibacterial agents, in industrial, household, and healthcare-related products, in consumer products, medical device coatings, optical sensors, and cosmetics, in the pharmaceutical industry, the food industry, in diagnostics, orthopedics, drug delivery, as anticancer agents, and have ultimately enhanced the tumor-killing effects of anticancer drugs [12-14]. The characteristic feature of nanomaterials such as size, shape, size distribution, surface area, solubility, and aggregation needs to be evaluated before assessing toxicity or biocompatibility [15]. In general, metal NPs can be prepared by various physical and chemical methods. Pulsed laser ablation in liquids is currently exploited as physical metal NPs preparation method. This method is based on pulse laser ablation from bulk metals in a liquid environment (e.g., water). One of the advantages of this method, compared to other conventional methods for preparing metal colloids, is the simplicity of the procedure; with respect to metals or solvents that do not need a catalyst, etc. Furthermore, it is a clean method due to the absence of chemical reagents or ions in the final preparation [16]. AgNPs have a great potential in cancer management because they have selectivity novel in disruption of mitochondrial respiratory chain leading to the production of reactive oxygen species (ROS), induced the expression of genes associated with DNA damage, and enhanced apoptosis of tumor cells [17]. AgNPs induce cell damage in a dose- and size-dependent manner; a higher dose and a smaller size lead to increased cytotoxic effects [18]. Lately, AshaRani et al. [19] reported that AgNPs inhibit proliferation of human glioblastoma cells. Sanpui et al. [20] demonstrated that AgNPs not only disrupting normal cellular function but also affecting the membrane integrity, induced various apoptotic signaling genes of mammalian cells leading to programmed cell death. The anticancer properties of silver nano-bioconjugates were non-toxic-to-non-cancerous buccal cells while evoking a strong cytotoxicity in the cancer cells [21]. Hsin et al. [22] reported that AgNPsinduced apoptosis in NIH3T3 cells by heightening the ROS generation and activated JNK pathway leading to mitochondria-dependent apoptosis. ROS are continually generated and eliminated in biological systems. They play an important role in a variety of normal biochemical 
functions and abnormality in their function results in pathological processes. Excessive production of ROS in the cell is known to induce apoptosis $[23,24]$. ROS generation has been shown to play an important role in apoptosis induced by treatment with AgNPs $[19,25,26]$. Hakkimane and Guru [27] have been developing method (hydrophilic drug isoniazid "INH") and successfully applied for the analysis of drugs in NP formulations. In this study, investigated cytotoxic effect of synthesized AgNPs by laser ablation of the metal plate immersed in polyvinylpyrrolidone (PVP) solution/deionized distilled water without adding any chemical materials, characterized with different techniques. On the basis of the aforementioned, this study was designed to assess the cytotoxicity of the synthesized AgNPs in AMJ13 human breast cancer cells and normal lymphocytes isolated of healthy donors. We attempt to provide concentrated insight into cytotoxic AgNPs between cancer and normal cells, and mechanism effects into cells through mitochondrial disrupt assay, DNA fragmentation assay, and glutathione (GSH) assay.

\section{METHODS}

\section{Synthesis of AgNPs}

A Q-switched Nd-YAG laser (type HUAFEI) operating at $1064 \mathrm{~nm}$ wavelength was employed to the synthesis of AgNPs by pulse laser ablation method. After laser-based setup was constructed, silver particles from metallic silver plate (2 mm thick and $99.999 \%$ purity) immersed in two types of liquid media, PVP solution $(2.5 \mathrm{mg} / \mathrm{ml}$ deionize distilled water [DDW]), and the other only DDW were ablated. The plate target was placed at the bottom of a glass cell containing $5 \mathrm{ml}$ liquid media volume and was rotated to be distributed uniformly. The number of pulses utilized to produce the AgNP solution was 1000 pulses, at laser energy shoot was $800 \mathrm{~mJ} /$ pulse, lasers pulse duration and repetition rate were $10 \mathrm{~ns}$ and $10 \mathrm{~Hz}$, respectively. The distance between target plate and laser source was $10 \mathrm{~cm}$, diameter of laser spot on a targeted plate was $1 \mathrm{~mm}$. After that, a yellowish colloidal solution of silver nanomaterial was obtained [28] with some modification.

\section{Cell lines}

An Iraqi woman patient of breast cancer cell line (AMJ13) was employed in this study, kindly provided by the Iraqi Center for Cancer and Medical Genetic Research. This cell line was cultivation and maintained in RPMI 1064 culture media with $2 \mathrm{mM}$ L-glutamine, HEPES, $100 \mu \mathrm{g} / \mathrm{mL}$ penicillin/gentamycin and $10 \%$ fetal calf serum (USbiological, USA), in a humidified atmosphere and $5 \% \mathrm{CO}_{2}$ at $37^{\circ} \mathrm{C}$.

\section{Subculture of cell lines}

Cultures were viewed using an inverted microscope to assess the degree of confluence and to confirm the absence of bacterial and fungal contaminants. Cell monolayer washed with phosphate buffer saline using a volume equivalent half of the volume of culture medium. Trypsin/versin solution was added on to the washed cell monolayer using $1 \mathrm{ml} / 50 \mathrm{~cm}^{2}$ of surface area. The flask was rotated to merge the monolayer with trypsin/versin solution. The flask was returned to the incubator and left for 2-5 min. The cells were examined using an inverted microscope (CKX41; Olympus, Japan) to ensure that all the cells were detached and floated; to be used it in the next experiments.

\section{Lymphocytes isolation}

Lymphocytes were obtained from healthy donors and cultured as described [29]. An effect of AgNPs on the growth rate was determined by MTT.

\section{Characterization of AgNPs}

\section{Ultraviolet (UV)-vis absorbance spectroscopy analysis}

Absorbance spectra of the AgNP solutions were measured by UV-visible double-beam spectrophotometer (Metertech SP-8001-Taiwan) directly after synthesis. Furthermore, the absorbance spectrum was measured at regular different time intervals (for 2 weeks) to same samples to authenticate the formation and stability of AgNPs in aqueous solution [30].
The zeta potential measurement

The zeta potential was carried out using zetaplus analysis (BrookhavenMilton Keynes, UK). Zeta potential analysis is important to measure the surface charge of AgNPs.

\section{Concentration measurement}

Concentration of the synthesized AgNPs was determined using atomic absorption spectroscopy (model Nov AA350, Germany).

\section{Transmission electron microscopy (TEM) analysis of AgNPs}

The morphology, size, and particle distributions of synthesized AgNPs were analysis used TEM (model CM10 pw6020, Philips-Germany) with image-j and GETDATA software programs. TEM samples were prepared by placing a drop of the suspension of AgNPs solution on grids and allowing it to evaporate.

\section{Cell viability assay}

The cytotoxic effect of synthesized AgNPs was assessed by MTT (Santa Cruz) cell viability assay against AMJ13 and lymphocytes. Cells were seeded into 96 -well transparent flat bottom plates (Santa Cruz) at a density of $1 \times 10^{4}$ cells/well and incubation at $37^{\circ} \mathrm{C}$ in a humidified incubator for $24 \mathrm{~h}$. After that, the cells were exposure with AgNPs-PVP and DDW (at laser energy $800 \mathrm{~mJ} /$ pulse) (0.78, $1.56,3.125,6.25,12.5$, and $25 \mu \mathrm{g} / \mathrm{ml}$ ) with different treatment periods $(24,48$, and $72 \mathrm{~h})$, in addition to control untreated cells. After end hours of incubation, the plates were aspirated to remove the exposure medium; the wells were washed with $100 \mu \mathrm{l}$ of PBS. Finally, $50 \mu \mathrm{l}$ of a solution 4,5-dimethylthiazol-2-yl-2,5-diphenyltetrazolium bromide (MTT, $5 \mathrm{mg} / \mathrm{mL}$ in PBS) was added to each well. After 2-4 h, media with MTT reagent was aspirated, then adding 100 $\mu \mathrm{L}$ of dimethylsulfoxide to solubilize the formazan crystals [31]. The optical density (OD) was measured with a microplate reader (FLUOstar OPTIMA - Germany) at an absorbance of $544 \mathrm{~nm}$. Viability was determined by the following equation: $\%$ viable cell $=0 \mathrm{D}$ of control cells-OD of treated cells/OD of control cells $\times 100$. The half maximal inhibitory concentration $\left(\mathrm{IC}_{50}\right)$ value was calculated and employed for next tests.

\section{Mitochondrial membrane potential assay}

This assay depends on the disruption of mitochondrial transmembrane potential (MTP) which is one of the earliest intracellular events that induction of apoptosis. Mitochondrion BioAssay Kit (USBiological) was employed to determine the early events of apoptosis, the treated and control cells were stained with fluorescent dyes. Cells were grown in 96-well flat bottom plate $\left(1 \times 10^{4}\right.$ cells/well $)$ and exposed to $\mathrm{IC}_{50}$ AgNPs for $24 \mathrm{~h}$ at $37^{\circ} \mathrm{C}$ with $5 \% \mathrm{CO}_{2}$. At the end time of incubation, the exposure media was aspirated. The diluted MitoCapture reagent was added ( $50 \mathrm{l} /$ well) over the cells for $15 \mathrm{~min}$. The cells were observed under a Leica inverted fluorescence microscope with the blue filters; the microphotographs were obtained with a Leica inverted fluorescent microscope DMI6000 digital camera.

\section{DNA fragmentation assay}

Cells were grown in $1 \times 10^{6}$ in flask $25 \mathrm{~cm}^{3}$ in the RPMI media for $24 \mathrm{~h}$ incubation. After that cells were exposed to $\mathrm{IC}_{50}$ value of AgNPs for 24 h. Cells were harvested with scraping. MagCore ${ }^{\circledR}$ Genomic DNA large volume kit is designed to extract genomic DNA from sample through Magnesia 16 System auto-extraction instrument. The kit contains all the reagents needed for purification processes and using magnetic particle technology. Reagents are supplied in prefilled cartridges, which can be loaded into machine directly without extra work. Easy select program code number (104) in MagCore $^{\circledR}$ and combine using MagCore ${ }^{\circledR}$ Genomic DNA large volume Kit can extract high-quality genomic DNA. The extracted DNA was mixed with DNA loading dye, and then applied to $1 \%$ agarose gel electrophoresis. After staining with ethidium bromide (US Biological, USA), the DNA was visualized by UV irradiation and photographed by gel documentation system (Sci-Plus, UK). Molecular weight marker ladder was used to characterize the DNA fragmentation. 


\section{GSH assay}

The cells were grown in flask $25 \mathrm{~cm}^{3}$ at $1 \times 10^{6}$ for $24 \mathrm{~h}$ incubation. Cells were exposed to $\mathrm{IC}_{50}$ value of AgNPs for $24 \mathrm{~h}$, without control cells exposure. The cells collected with supernatant in a sterile tube and subject to freeze-thaw cycles to break the cell membranes. The centrifugation for tubes was done at $5000 \mathrm{rpm}$ for $15 \mathrm{~min}$. At $20^{\circ} \mathrm{C}$, the supernatant was transferred to new tubes (samples). The assay samples and standard are incubated together with GSH-horseradish peroxidase (HRP) conjugate for $1 \mathrm{~h}$. A competition for limited antibody binding sites on the plate occur between GSH-HRP conjugate and GSH in the samples and standards. After the incubation, the wells are decanted and washed 5 times. The wells are then incubated with substrate for HRP enzyme. Finally, a stop solution is added to terminate the reaction, which will then turn the solution yellow. The intensity of color is measured spectrophotometrically at $450 \mathrm{~nm}$ in a microplate reader (FLUOstar OPTIMA). The intensity of the color is inversely proportional to the GSH concentrations in the sample or standard. A standard curve is plotted relating the intensity of the color (OD) to the concentration of the standards. The GSH concentration in each sample is interpolated from this standard curve.

\section{Statistical analysis}

The Statistical Analysis System - SAS [32] program was used to affect different factors in study parameters. Least significant difference test was used to significant compare between means in this study.

\section{RESULTS AND DISCUSSION}

\section{Synthesis and characterization of AgNPs}

The stock concentrations for both a synthesized AgNPs-PVP and AgNPs-DDW by pulse laser ablation were $50 \mu \mathrm{g} / \mathrm{mL}$. The synthesis of AgNPs using the pulse laser ablation on silver metal plate was confirmed by the color change. The color of the solutions changed from colorless to yellowish during the ablation and to yellowish-brown depending concentration [28]. To monitor the synthesis and stability of
AgNPs, the absorption spectra of the AgNPs were observed using UVvisible spectroscopy for same samples several times for 2 weeks. This indicates that AgNPs formation occurs due to the excitation of surface plasmon vibration (SPR) of the particles. The typical SPR of both AgNPs was observed between 402 and $410 \mathrm{~nm}$ Fig. 1. Observation of this peak, assigned to a surface plasmon, is well documented for various metal NPs with sizes ranging from 2 to $100 \mathrm{~nm}$ [33].

This absorbance peak indicated the spherical shape of the prepared AgNPs. The zeta potential of the AgNPs-PVP and AgNPs-DDW were around -17.44 and $-19.01 \mathrm{mV}$, respectively. The zeta potential values are providing convincing evidence that the particles have no tendency to agglomerate Fig. 2.

The zeta values that obtained from this study for the two types of AgNPs prepared corresponds to previous studies results [34,35]. As well, the UV-visible spectra of the AgNPs in PVP and DDW were measured after 1 and 2 weeks to investigate the capability of fluids as a stabilizer. The absorption spectrum in Fig. 1 does not show a significant change in the fresh sample compared to old sample in DDW, but a marked reduction in absorbance peak can be seen in PVP. Although the spectrum peaks at these wavelengths did not deviate from 410 , the size and particle size distribution of both AgNPs in the aqueous solutions were observed by TEM micrographs with histogram, with a relatively narrow particle size distribution as Fig. 3. The TEM micrographs for AgNPs-PVP analyzed were revealed that the average size of the particles is $28.43 \mathrm{~nm}$ and the largest proportion of particles ranging from 10 to $40 \mathrm{~nm}$. While the TEM micrographs for AgNPs-DDW analysis were revealed that the average size of the particles is approximately $(21.20 \mathrm{~nm})$ and the largest proportion of particles ranging from 10 to $35 \mathrm{~nm}$ Fig. 3. The NPs shape observed by TEM was almost of spherical shape of both synthesized AgNPs, this corresponds with reported [36]. This type of NPs shape is suitable for drug loading and most biological applications [37]. Sivakumar et al. [38] found that the synthesized silver nanocubes using
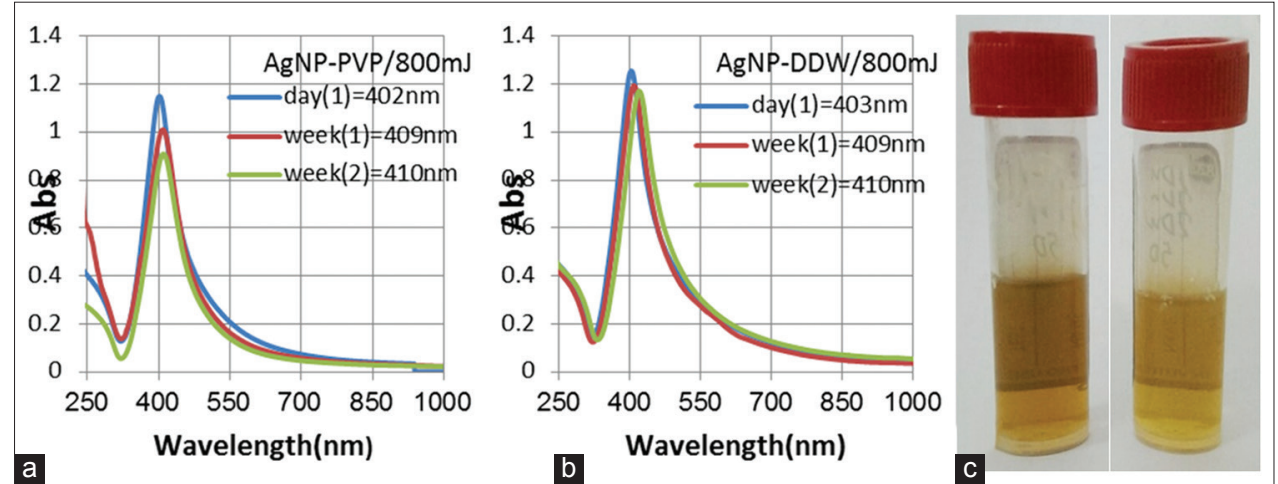

Fig. 1: Ultraviolet-vis spectrum of synthesized silver nanoparticles (AgNPs) by laser ablation: (a) in polyvinylpyrrolidone solution; (b) in deionize distilled water; (c) synthesized AgNPs coloidals

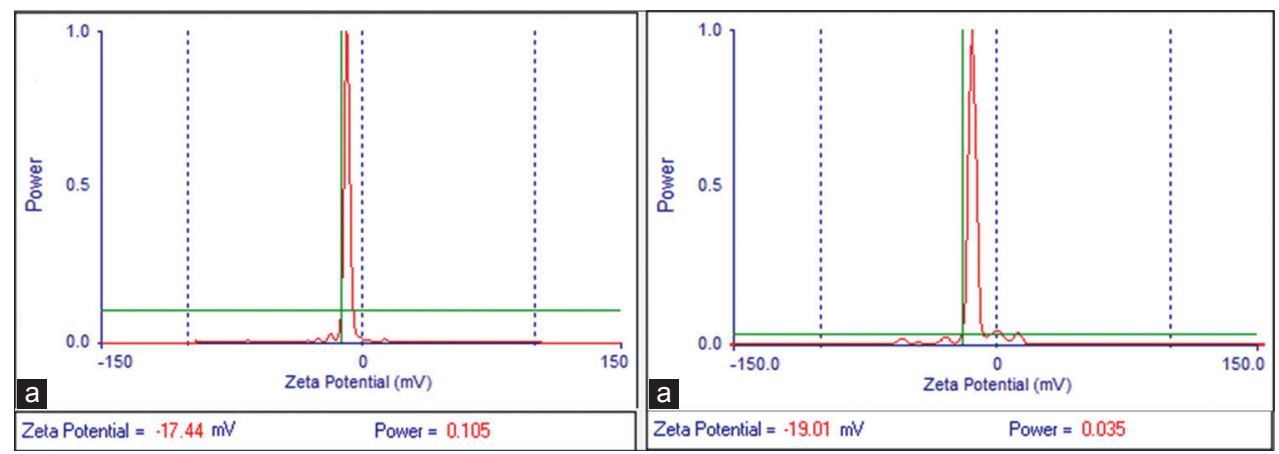

Fig. 2: Zeta potential analysis of synthesized silver nanoparticles (AgNPs) using the laser device by pulse laser ablation at laser energy 800 mJ/pulse: (a) AgNPs-polyvinylpyrrolidone; (b) AgNPs-deionize distilled water 
Peltophorum pterocarpum is possible that using as an antimicrobial agent against plant morbific fungi.

\section{Cytotoxicity and determination of minimum IC $_{50}$ of AgNPs}

The cytotoxicity of AgNPs initially was evaluated by MTT assay following exposure of AMJ13 cells and lymphocytes to increasing concentrations and 3 times 24, 48, and 72 h. The cells were treated with 2 types of synthesized AgNPs-PVP and AgNPs-DDW with same concentrations selected $(0.78-25 \mu \mathrm{g} / \mathrm{ml})$. The cell viability assay is one of the important methods for toxicology analysis which explains the cellular response to toxic materials, and it can provide information on cell death, survival, and metabolic activities [19]. The results from the cell viability assay showed a concentration-dependent pattern and exposure periods in both cell types. The size $20 \mathrm{~nm}$ AgNPs were more toxic than the size $50 \mathrm{~nm}$ AgNPs. The behavioral responses and deviations were dose-dependent, increasing by increasing the dose [39]. AgNPs (PVP or DDW) cause significant cell death in breast cancer cells than lymphocytes at tested concentrations (Figs. 4 \& 5 a and b). This result demonstrated that AgNPs-PVP was slightly more potent than AgNPs-DDW in AMJ13 cells. Earlier reports indicated that starch, bovine serum albumin, and PVP-modified AgNPs were toxic to cells $[40,41]$. With increasing concentration, the survival rate of AMJ13 cells treated with both AgNPs decreased more sharply than lymphocytes treated with AgNPs. Thus, it could be a suitable model for the development of novel therapeutic approaches to combat breast cancer. Franco-Molina et al. [42] reported that colloidal silverinduced dose-dependent cytotoxic effect on MDA-MB-231 breast cancer cells. The results revealed that both AgNPs forms were high cytotoxic on cancer cells comparison of normal cells. The synthesized silver and gold NPs using the plant extract of Eclipta prostrata were found to be toxic against HT 29 cancer cells [43]. At $24 \mathrm{~h}$ of treatment, $\mathrm{IC}_{50}$ on AMJ13 was $6.25 \mu \mathrm{g} / \mathrm{ml}$ for both AgNPs-PVP and DDW, which decreased the cell viabilities to $50 \%$ subtracted from control. Since the inhibition rate of normal lymphocytes was very low compared with the cancer cells, $\mathrm{IC}_{50}$ did not appear during all three exposure periods. Therefore, in further experiments, we focused on breast cancer cells.
Govindaraju et al. [44] reported that AgNPs caused a significant cytotoxicity in HL60 and HeLa cells in a concentration-dependent manner with the $\mathrm{IC}_{50}$ value of 2.84 and $4.91 \mu \mathrm{g} / \mathrm{ml}$, respectively, whereas IC $_{50}$ for normal mononuclear was $63.37 \mu \mathrm{g} / \mathrm{ml}$. Cytotoxicity of AgNPs on MCF-7 breast cancer cell line was able to reduce viability in a dose-dependent manner, and the AgNPs IC I0 $_{50}$ on MCF-7 was found to be $50 \mu \mathrm{g} / \mathrm{ml}[34]$.

\section{DNA fragmentation}

The DNA laddering technique is used to visualize the endonuclease cleavage products of apoptosis [45]. This assay involves extraction of DNA, the DNA damage represented in the formation of long smear with ladder pattern in agarose gel for the treated AMJ13 cells, whereas the untreated cells showed minimal DNA damage as a very shallow smear with no ladder pattern in the gel after electrophoresis (Fig. 6) shows ladder-like pattern of DNA fragmentation is approximately 4000$100 \mathrm{bp}$. DNA fragmentation is broadly considered as a characteristic feature of apoptosis [46]. Apoptosis of the AgNP-treated cells was accompanied by a reduction in the percentage of cells in G0/G1 phase and an increase in the percentage of $\mathrm{G} 2 / \mathrm{M}$ phase cells, indicating cell cycle arrest atG2/M [47]. AgNPs are known to induce cytotoxicity in several types of cancer cells by generation of ROS and mitochondrial dysfunction, thus death cells [48]. The ROS can act as signal molecules promoting cell cycle progression and can induce DNA damage [49]. Induction of apoptosis can be confirmed by two factors such as irregular reduction in size of cells, in which the cells are reduced and shrunken, and finally DNA fragmentation [50]. These results clearly indicate that the DNA "laddering" pattern in AMJ13 cells treated with AgNPs $\mathrm{IC}_{50}$ is one of the reasons for cell death.

Effect of synthesized AgNPs on reduced GSH level in cytoplasm cells

To verify the GSH level, AMJ13 cancer cell line was $\mathrm{IC}_{50}$ treated with two types of synthesized AgNPs-PVP and AgNPs-DDW (at laser energy $800 \mathrm{~mJ} /$ pulse) separately, which was $6.25 \mu \mathrm{g} / \mathrm{ml}$ for two types. A standard curve is plotted relating the intensity of the color (OD) to the

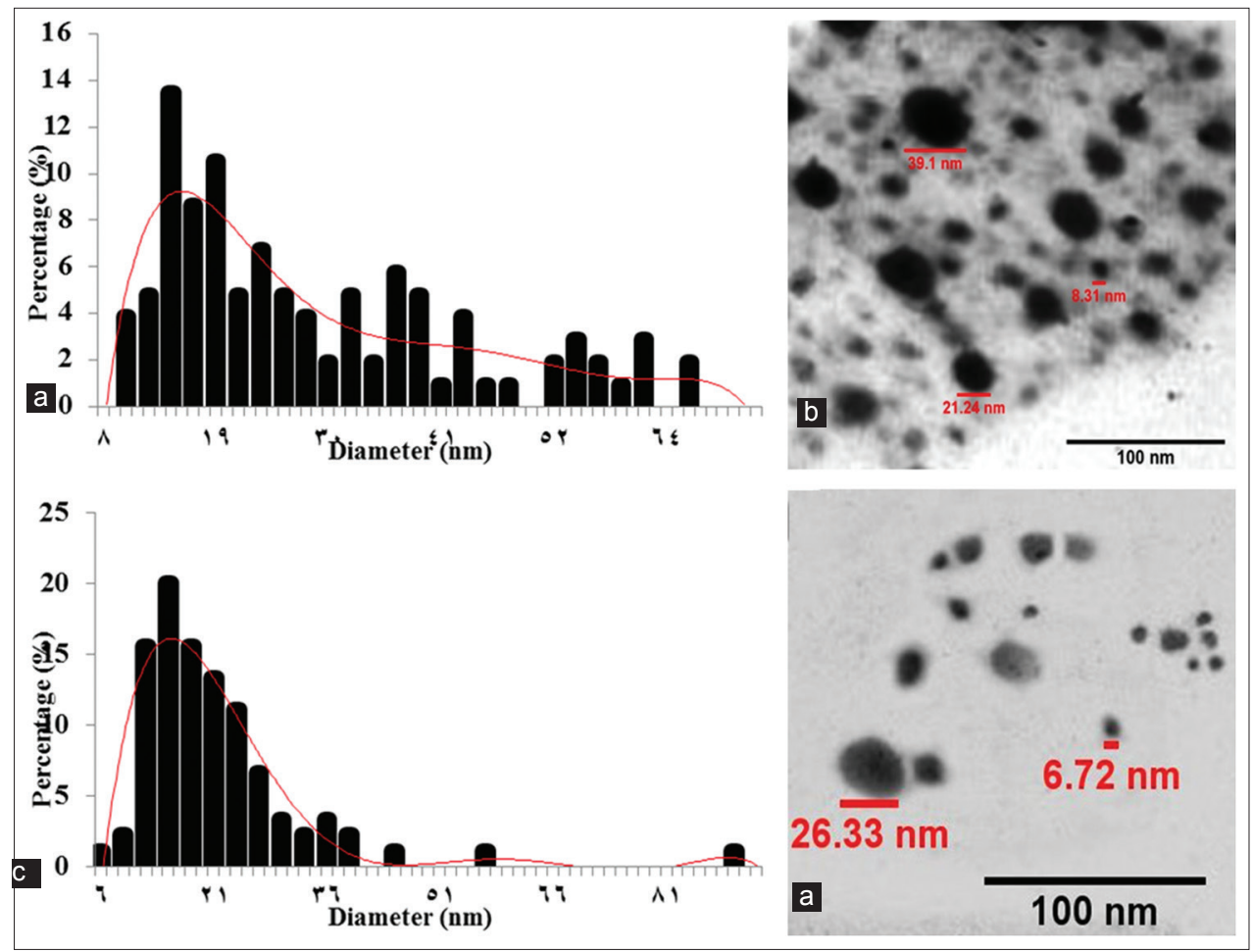

Fig.3: Characterization of synthesized silver nanoparticles (AgNPs) by pulse laser ablation using transmission electron microscope transmission electron microscopy (TEM). (a) Particle size distributions for AgNPs-polyvinylpyrrolidone (PVP); (b) TEM images of AgNPsPVP; (c) particle size distributions AgNPs- deionize distilled water (DDW); (d) TEM images of AgNPs-DDW 


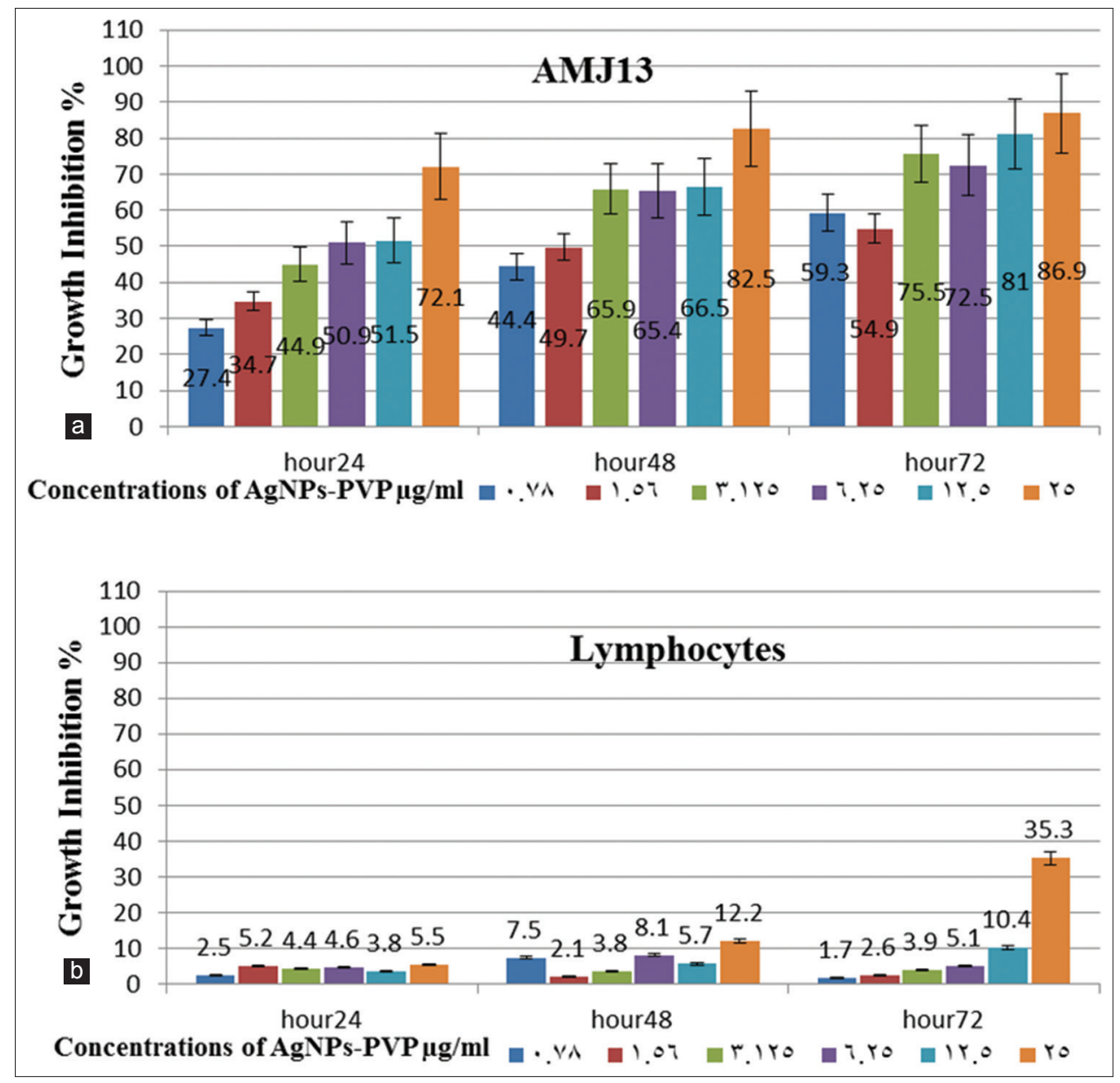

Figure 4: Cytotoxic activity of AgNPs-PVP during 24, 48, and 72hrs of exposure on: a) AMJ13 breast cancer cell line; b) Lymphocytes.

concentration of the standards to extract the standard equation of the curve. The GSH concentration in each sample is interpolated from this standard equation. The standard equation is used to determine the GSH concentration in each sample Fig. 7.

In this assay, the effect of $\mathrm{IC}_{50}$ for both synthesized AgNPs showed slightly decreased in GSH level for treated AMJ13 cells of comparison with the control (untreated cells) after $24 \mathrm{~h}$ of treatment, with nonsignificant variation Table 1.

Reduced GSH, a thiol-containing tripeptide, predominantly exists at high levels in reduced form and functions by scavenging ROS to maintain balance in the cellular redox environment and protect cells against oxidative stress [51]. Xia et al. [52] reported that AgNPs decreased (GSH) levels and increased generation of (ROS) in cells. In a previous study by Swanner et al. [53] reported that GSH levels can modulate the cytotoxicity of AgNPs in both MCF-7, and MCF-10A breast cancer cells, but did not have much effect on AgNPs activity in MDA-MB-231 breast cancer cells. Intracellularly, released $\mathrm{Ag}^{+}$ions interact with thiol groups of antioxidants such as GSH, superoxide dismutase and thioredoxin, leading to increased lipid peroxidation, oxidative stress, DNA damage, and subsequent apoptotic cell death [54,55]. Biological evaluation of the NPs showed significant antimicrobial and antioxidant activity [56]. Thiol molecules are found conjugated to several membrane proteins in the cell membrane, cytoplasm, and mitochondria, which may serve as targets for AgNPs or $\mathrm{Ag}^{+}$ions [57]. Emphasized, Fahrenholtz et al. [35] during treatment A2780, SKOV3, and OVCAR3 cells with PVP-coated AgNPs (10 and $100 \mu \mathrm{g} / \mathrm{ml}$ ) for $24 \mathrm{~h}$ to quantify the cellular content of both oxidized (GSSG) and reduced GSH. The net effect of these changes was a decrease in the GSH/GSSG ratio in SKOV3 cells but not in OVCAR3 and A2780 cells. The lack of correlation between the effects of AgNPs on
GSH/GSSG and the relative sensitivity of ovarian cancer cells to AgNPs exposure indicated that modulation of the GSH/GSSG ratio is unlikely to be the dominant mechanism by which AgNPs exert their cytotoxic effects.

\section{Mitochondrial permeability transition apoptosis test}

Mitochondrial transmembrane potential (MTP) is an early event in apoptosis. The apoptosis cells were evaluated using MitoPT apoptosis Kit (cationic aye) that were demonstrated that the onset of apoptosis in mitochondria was almost $6 \mathrm{~h}$ after exposure to $\mathrm{IC}_{50}$ AgNPs for two types. Mitochondria-mediated apoptosis undergoes two major changes which include changes in the permeabilization of the outer mitochondrial membrane and the loss of the electrochemical gradient [58]. Membrane depolarization is mediated by the mitochondrial permeability transition pore. Prolonged mitochondrial permeability transition pore opening leads to a damage outer mitochondrial membrane [59]. These results indicate that AgNPs could induce apoptosis through a mitochondria-mediated apoptosis pathway, as confirmed in (Fig. 8), observed following treatment of AgNPs- $\mathrm{I}_{\mathrm{C5}} 0$ for 6 and $24 \mathrm{~h}$, disappearance of red fluorescence and emergence of green fluorescence in treated AMJ13 cells (green cells), which intension with exposure period increased. While the untreated AMJ13 cells appeared of red fluorescence (red cells). Gurunathan et al. [60] were observed disappearance of red fluorescence and emergence of green fluorescence in A549 cancer cells, whereas the green fluorescence was very weak in L132 normal cells treated with AgNPs for $12 \mathrm{~h}$, indicating that AgNPs could cause MTP collapse significantly higher in cancer cells than normal cells. Govender et al. [61] observed a significant increase in $\mathrm{mt}$ depolarization after AgNP treatment, with an accompanied decrease in ATP concentration. They concluded that the high levels of bax expression, high mt depolarization, and decreased ATP suggest 


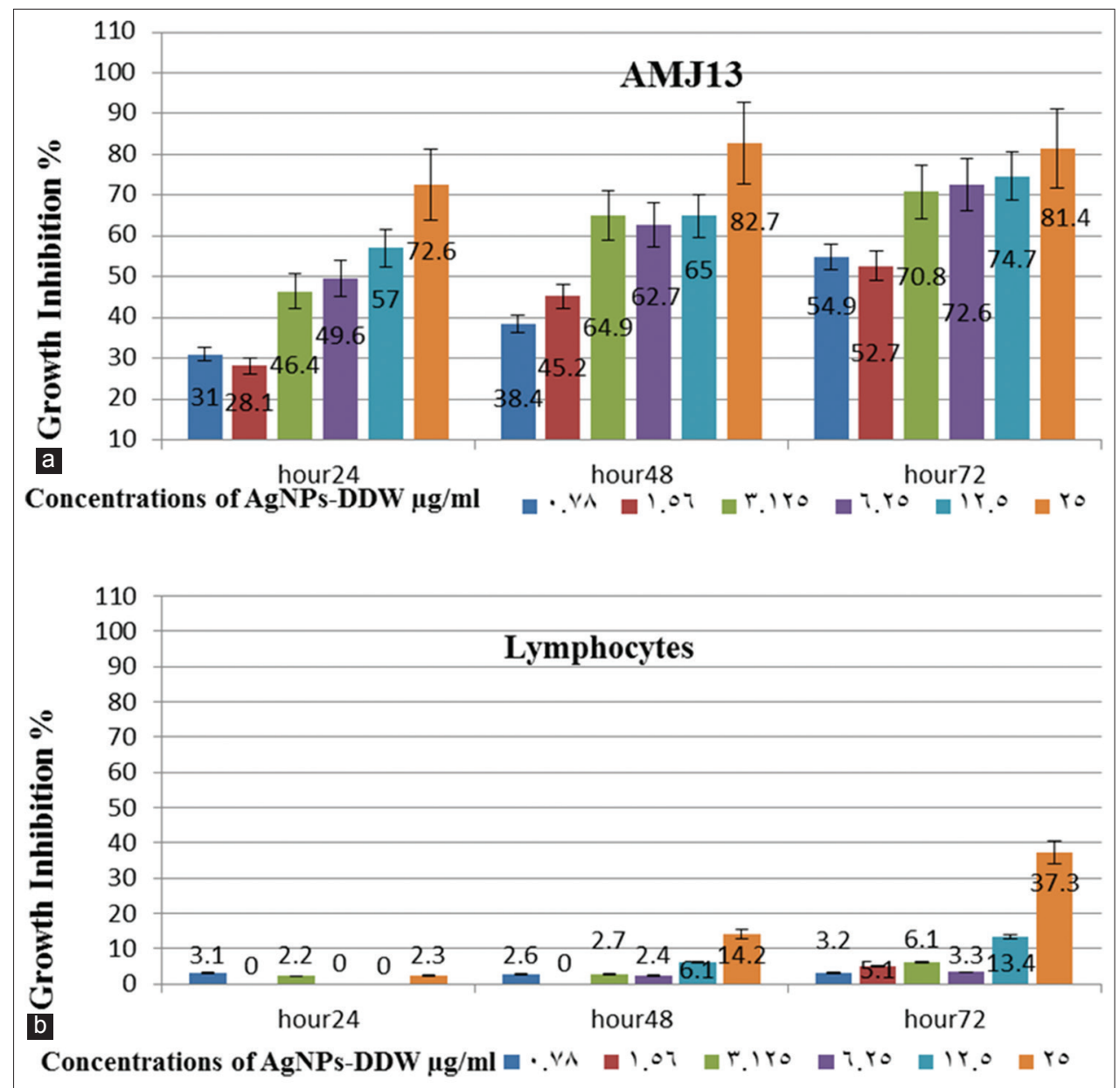

Fig. 5: Cytotoxic activity of silver nanoparticles - deionize distilled water during 24, 48, and 72 h of exposure on: (a) AMJ13 breast cancer cell line; (b) lymphocytes

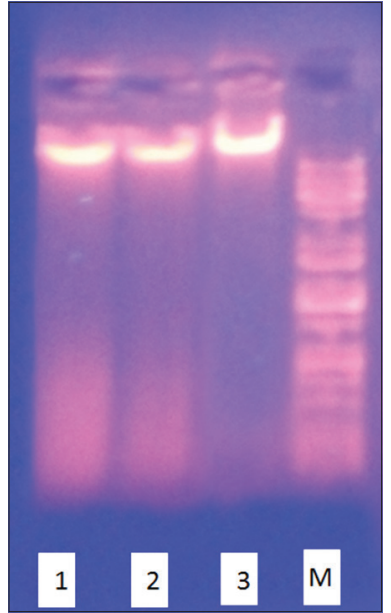

Fig. 6: Effect of silver nanoparticles (AgNPs) on DNA fragmentation. AMJ13 cells were treated with $50 \%$ inhibitory concentration for $24 \mathrm{~h}$ and DNA fragmentation was analyzed by agarose gel electrophoresis. Lane M, 1 kB ladder; lane 3, control; lane 1, AgNPs-deionize distilled water; lane 2, AgNPspolyvinylpyrrolidone

that AgNP induces cellular apoptosis in cancerous lung cells through the intrinsic apoptotic pathway. Several studies also suggest that NPs seem to be localized in mitochondria and cause oxidative stress as well as potentiate structural damage and eventually lead to toxicity to the cells $[62,63]$.

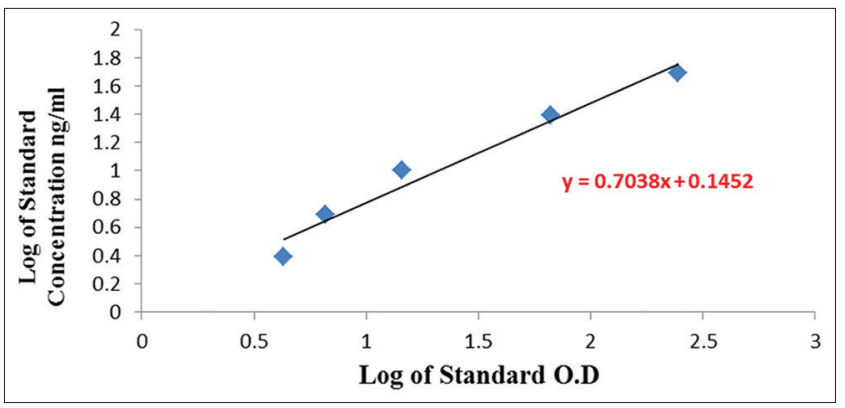

Fig. 7: Standard curve to the concentration glutathione in standards

Table 1: Levels of (GSH) in the cytoplasm of exposed AMJ13 to AgNPs (PVP/DDW)

\begin{tabular}{llll}
\hline $\begin{array}{l}\text { Type of } \\
\text { cells }\end{array}$ & Type of AgNPs & Level of GSH (ng/ml) & $\mathbf{p}$ \\
\hline AMJ13 & AgNPs-PVP & 0.729 & \\
& AgNPs-DDW & 0.750 & $0.263 \mathrm{NS}$ \\
& Control (untreated) & 0.996 & \\
\hline
\end{tabular}

NS: Non-significant. AgNPs: Silver nanoparticles, GSH: Glutathione, DDW: Deionized distilled water, PVP: Polyvinylpyrrolidone

\section{CONCLUSION}

In this study, synthesized spherical AgNPs is a green, environmentally friendly approach, cost-effective, and rapid method for synthesis of 


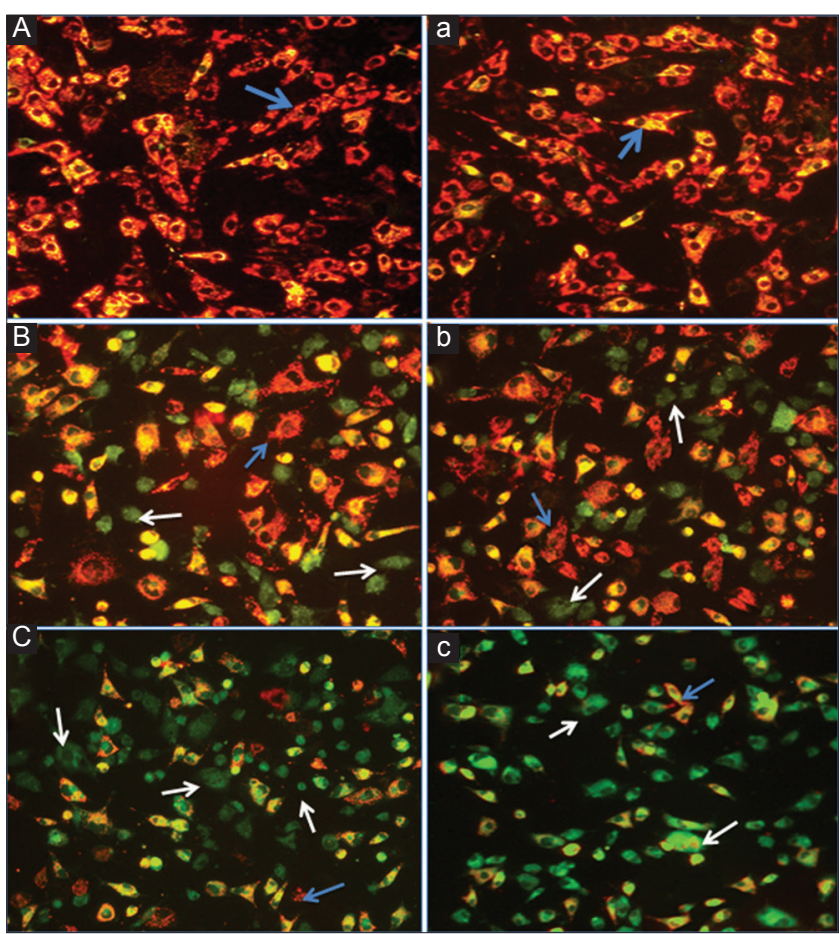

Fig. 8: AMJ13 cell line treated with IC50 silver nanoparticles (AgNPs) (200x): (Capital letters) AgNPs-polyvinylpyrrolidone treated and (small letters) AgNPs-DDW treated: (a) untreated (control) cells; (b) cells 6 h treated; (c) cells 24 h treated. Red viable cells (blue arrow), green apoptotic cells (white arrow)

AgNPs using a novel laser at energy $800 \mathrm{~mJ} /$ pulse. The present study demonstrated that AgNPs-PVP and AgNPs-DDW had a strong inhibitory effect on the growth of AMJ13 cells by different concentrations, while the effect of AgNPs-PVP and AgNPs-DDW viability lymphocytes were very low. The overall results indicated that the physically synthesized AgNPs were exhibited dose-dependent cell death in AMJ13 breast cancer cell line, suggesting that physically synthesized AgNPs might be a potential alternative agent for human breast cancer therapy. This study also could provide basic information about the mechanisms involved in AgNPs-induced apoptosis of AMJ13 cells. From the cell viability assay, the $\mathrm{IC}_{50}$ was found to be $6.25 \mu \mathrm{g} / \mathrm{mL}$. Since lymphocyte $\mathrm{IC}_{50}$ did not appear during all three exposure periods. This report also suggests that AgNPs induce cell death through disrupted mitochondrial membrane, DNA fragmentation, and but the results revealed non-significant GSH level assay.

\section{AUTHORS CONTRIBUTION}

Nawfal N. and Mohammed Q. prepared AgNPs by pulse laser ablation method and characterization of AgNPs. Evaluation of AgNPs cytotoxicity was done by Nahi Y. All the authors contributed ideas and thought to the writing of this paper.

\section{CONFLICT OF INTERESTS}

\section{Declared none.}

\section{REFERENCES}

1. Chan K, Morris GJ. Chemoprevention of breast cancer for women at high risk. Semin Oncol 2006;33:642-6.

2. Jenal A, Thmas A, Murry T. Cancer stastics. CA. Cancer J Clin 2002;52:23-37.

3. Johnston SR. Acquired tamoxifen resistance in human breast cancerpotential mechanisms and clinical implications. Anticancer Drugs 1997;8:911-30.

4. Kato S, Endoh H, Masuhiro Y, Kitamoto T, Uchiyama S, Sasaki H, et al. Activation of the estrogen receptor through phosphorylation by mitogen-activated protein kinase. Science 1995;270:1491-4

5. Lupu R, Cardillo M, Cho C. The signifiance of heregulin in breast cancer tumor progression and drug resistance. Breast Cancer Res Treat 1996;38:57-66.

6. Brown K. Breast cancer chemoprevention: Risk-benefi effcts of the antioestrogen tamoxifen. Expert Opin Drug Saf 2006;1:253-67.

7. Smith LL, Brown K, Carthew P. Chemoprevention of breast cancer by tamoxifen: Risks and opportunities. Crit Rev Toxicol 2000;30:571-94.

8. Liu H, Liu Y, Wang Z, He P. Facile synthesis of monodisperse, sizetunable snS nanoparticles potentially for solar cell energy conversion. Nanotechnology 2010;21:105707.

9. Chen X, Schluesener HJ. Nanosilver: A nanoproduct in medical application. Toxicol Lett 2008;176:1-2.

10. Yu MK, Park J, Jon S. Targeting strategies for multifunctional nanoparticles in cancer imaging and therapy. Theranostics 2012;2:3-44.

11. Sriram MI, Kanth SB, Kalishwaralal K, Gurunathan S. Antitumor activity of silver nanoparticles in Dalton's lymphoma ascites tumor model. Int J Nanomed 2010;5:753-62.

12. Gurunathan S, Park JH, Han JW, Kim JH. Comparative assessment of the apoptotic potential of silver nanoparticles synthesized by Bacillus tequilensis and Calocybe indica in MDA-MB-231 human breast cancer cells: Targeting p53 for anticancer therapy. Int J Nanomed 2015;10:4203-22.

13. Li WR, Xie XB, Shi QS, Zeng HY, Ou-Yang YS, Chen YB. Antibacterial activity and mechanism of silver nanoparticles on Escherichia coli. Appl Microbiol Biotechnol 2010;8:1115-22.

14. Chernousova S, Epple M. Silver as antibacterial agent: Ion, nanoparticle, and metal. Angew Chem Int Ed 2013;52:1636-53.

15. Murdock RC, Braydich-Stolle L, Schrand AM, Schlager JJ, Hussain SM. Characterization of nanomaterial dispersion in solution prior to in vitro exposure using dynamic light scattering technique. Toxicol Sci 2008:101:239-53.

16. Liu P, Cui H, Wang CX, Yang GW. From nanocrystal synthesis to functional nanostructure fabrication: Laser ablation in liquid. Phys Chem Chem Phys 2010;12:3942-52.

17. Asharani PV, Hande MP, Valiyaveettil S. Anti-proliferative activity of silver nanoparticles. BMC Cell Biol 2009;10:65.

18. Zhang XF, Choi YJ, Han JW, Kim E, Park JH, Gurunathan S, et al. Differential nanoreprotoxicity of silver nanoparticles in male somatic cells and spermatogonial stem cells. Int J Nanomedicine 2015;10:1335- 57

19. AshaRani PV, Kah Mun GL, Hande MP, Valiyaveettil S. Cytotoxicity and genotoxicity of silver nanoparticles in human cells. ACS Nano 2009;3:279-90. 
20. Sanpui P, Chattopadhyay A, Ghosh SS. Induction of apoptosis in cancer cells at low silver nanoparticle concentrations using chitosan nanocarrier. ACS Appl Mater Interfaces 2011;3:218-28.

21. Preethi R, Padma PR. Anticancer activity of silver nanobioconjugates synthesized from Piper betle leaves extract and its active compound eugenol. Int J Pharm Pharm Sci 2016;8:201-5.

22. Hsin YH, Chen CF, Huang S, Shih TS, Lai PS, Chueh PJ. The apoptotic effect of nanosilver is mediated by a ROS- and JNK-dependent mechanism involving the mitochondrial pathway in NIH3T3 cells. Toxicol Lett 2008;179:130-9.

23. Martindale JL, Holbrook NJ. Cellular response to oxidative stress: Signaling for suicide and survival. J Cell Physiol 2002;192:1-5.

24. Sastre J, Pallardo FV, de la Assunci' on JG, Vi' na J. Mito-chondria, oxidative stress and aging. Free Radic Res 2000;32:189-98.

25. Carlson C, Hussain SM, Schrand AM, Braydich-Stolle LK, Hess KL, Jones RL, et al. Unique cellular interaction of silver nanoparticles: Size-dependent generation of reactive oxygen species. J Phys Chem B 2008; $112: 13608-19$

26. Foldbjerg R, Olesen P, Hougaard M, Dang DA, Hoffmann HJ, Autrup $\mathrm{H}$, et al. PVP-coated silver nanoparticles and silver ions induce reactive oxygen species, apoptosis and necrosis in THP-1 monocytes. Toxicol Lett 2009;190:156-62.

27. Hakkimane SS, Guru BR. Nano formulation analysis: Analytical method development of isoniazid and simultaneous estimation of antitubercular drugs isoniazid and rifampicin by reverse phase high pressure liquid chromatography. Asian J Pharm Clin Res 2017;10:3305.

28. Tajdidzadeh M, Azmi BZ, Yunus WM, Talib ZA, Sadrolhosseini $\mathrm{AR}$, Karimzadeh $\mathrm{K}$, et al. Synthesis of silver nanoparticles dispersed in various aqueous media using laser ablation. Sci World J 2014;2014:324921.

29. Premanathan M, Arakaki R, Izumi H, Kathiresan K, Nakano M, Yamamoto $\mathrm{N}$, et al. Antiviral properties of a mangrove plant, Rhizophora apiculata blume, against human immunodeficiency virus. Antiviral Res 1999;44:113-22

30. Elshawy OE, Helmy EA, Rashed LA. Preparation, characterization and in vitro evaluation of the antitumor activity of the biologically synthesized silver nanoparticles. Adv Nanopart 2016;5:149-66.

31. Zahedifard M, Faraj FL, Paydar M, Looi CY, Hajrezaei M, Hasanpourghadi, M, et al. Synthesis, characterization and apoptotic activity of quinazolinone Schiff base derivatives toward MCF-7 cells via intrinsic and extrinsic apoptosis pathways. Sci Rep 2015;5:11544.

32. SAS. Statistical Analysis System, User's Guide. Statistical. Version 9. $1^{\text {th }}$ ed. N.C. USA: SAS. Inst. Inc. Cary.; 2012.

33. Gurunathan S, Han J, Abdal Dayem A, Eppakayala V, Park JH, Cho S, et al. Green synthesis of anisotropic silver nanoparticles and its potential cytotoxicity in human breast cancer cells (MCF-7). J Ind Eng Chem 2013c;19:1600-5.

34. El-Sonbaty SM. Fungus-mediated synthesis of silver nanoparticles and evaluation of antitumor activity. Cancer Nanotechnol 2013;4:73-9.

35. Fahrenholtz CD, Swanner J, Ramirez-Perez M, Singh RN. Heterogeneous responses of ovarian cancer cells to silver nanoparticles as a single agent and in combination with cisplatin. $J$ Nanomater 2017;2017:1-11.

36. Hajiesmaeilbaigi F, Mohammadalipour A, Sabbaghzadeh J, Hoseinkhani S, Fallah HR. Preparation of silver nanoparticles by laser ablation and fragmentation in pure water. Laser Physics Lett 2006;3:252-6

37. Khanna PK, Nair CK. Synthesisof silvernanoparticles using cod liver oil (fish oil): Green approach to nanotechnology. Int J Green Nanotechnol Physics Chem 2009;1:3-9.

38. Sivakumar P, Karthika P, Sivakumar P, Muralidharan NG, Devendran $\mathrm{P}$, Renganathan S. Bio-Synthesis of silver nano cubes from active compound quercetin-3-O-B-dgalactopyranoside containing plant extract and its antifungal application. Asian $\mathrm{J}$ Pharm Clin Res 2013;6:76-9.

39. Elkhawass EA, Mohallal ME, Soliman MF. Acute toxicity of different sizes of silver nanoparticles intraperitonally injected in Balb/C mice using two toxicological methods. Int J Pharm Pharm Sci 2014;7:94-9.

40. Asharani PV, Lian Wu Y, Gong Z, Valiyaveettil S. Toxicity of silver nanoparticles in zebrafish models. Nanotechnology 2008;19:255102.

41. Larese FF, D’Agostin F, Crosera M, Adami G, Renzi N, Bovenzi M, et al. Human skin penetration of silver nanoparticles through intact and damaged skin. Toxicology 2009;255:33-7.

42. Franco-Molina MA, Mendoza-Gamboa E, Sierra-Rivera CA. Antitumor activity of colloidal silver on MCF-7 human breast cancer cells. J Exp Clin Can Res 2010;29:148.

43. Rajasekar A, Janakiraman V, Govindarajan K. In vitro cytotoxic study of green synthesized gold and silver nanoparticles using Eclipta prostrata (L.) Against Ht-29 Cell Line. Asian J Pharm Clin Res 2016;9:189-93.

44. Govindaraju K, Krishnamoorthy K, Alsagaby SA, Singaravelu G, Premanathan M. Green synthesis of silver nanoparticles for selective toxicity towards cancer cells. IET Nanobiotechnol 2015;9:325-30.

45. Kar B, Sivamani S. Apoptosis: Basic concepts, mechanisms and clinical implications. Int J Pharm Sci Res 2015;6:940-50.

46. Allen RT, Hunter WJ $3^{\text {rd }}$, Agrawal DK. Morphological and biochemical characterization and analysis of apoptosis. J Pharmacol Toxicol Methods 1997;37:215-28.

47. Lee YS, Kim DW, Lee YH, Oh JH, Yoon S, Choi MS, et al. Silver nanoparticles induce apoptosis and $\mathrm{G} 2 / \mathrm{M}$ arrest via $\mathrm{PKC} \zeta$-dependent signaling in A549 lung cells. Arch Toxicol 2011;85:1529-40.

48. Zhang XF, Gurunathan S. Combination of salinomycin and silver nanoparticles enhances apoptosis and autophagy in human ovarian cancer cells: An effective anticancer therapy. Int J Nanomedicine 2016;11:3655-75.

49. Hu R, Yong KT, Roy I, Ding H, He S, Prasad PN, et al. Metallic nanostructures as localized plasmon resonance enhanced scattering probes for multiplex dark field targeted imaging of cancer cells. J Phys Chem C Nanomater Interfaces 2009; 113:2676-84

50. Gurunathan S, Han JW, Eppakayala V, Jeyaraj M, Kim JH. Cytotoxicity of biologically synthesized silver nanoparticles in MDA-MB-231 human breast cancer cells. Biomed Res Int 2013;2013:535796.

51. Masip L, Veeravalli K, Georgiou G. The many faces of glutathione in bacteria. Antioxid Redox Signal 2006;8:753-62

52. Xia T, Kovochich M, Brant J, Hotze M, Sempf J, Oberley T, et al. Comparison of the abilities of ambient and manufactured nanoparticles to induce cellular toxicity according to an oxidative stress paradigm. Nano Lett 2006;6:1794-807.

53. Swanner J, Mims J, Carroll DL, Akman SA, Furdui CM, Torti SV, et al. Differential cytotoxic and radiosensitizing effects of silver nanoparticles on triple-negative breast cancer and non-triple-negative breast cells. Int J Nanomed 2015;10:3937-53

54. Arora S, Jain J, Rajwade JM, Paknikar KM. Cellular responses induced by silver nanoparticles: In vitro studies. Toxicol Lett 2008;179:93-100.

55. Zhang T, Wang L, Chen Q, Chen C. Cytotoxic potential of silver nanoparticles. Yonsei Med J 2014;55:283-91.

56. Kurian GA, Vishnu AV, Subhash N, Shakilabanu A. Characterization and biological evaluation of silver nanoparticles synthesized by aqueous root extract of Desmodium gangeticum for its antioxidant, antimicrobial and cytotoxicity. Int J Pharm Pharm Sci 2014;7:182-6.

57. Almofti MR, Ichikawa T, Yamashita K, Terada H, Shinohara Y. Silver ion induces a cyclosporine a-insensitive permeability transition in rat liver mitochondria and release of apoptogenic cytochrome $\mathrm{C}$. J Biochem 2003;134:43-9.

58. Kimata M, Matoba S, Iwai-Kanai E, Nakamura H, Hoshino A, Nakaoka M, et al. P53 and TIGAR regulate cardiac myocyte energy homeostasis under hypoxic stress. Am J Physiol Heart Circ Physiol 2010;299:H1908-16.

59. Rasola A, Bernardi P. The mitochondrial permeability transition pore and its involvement in cell death and in disease pathogenesis. Apoptosis 2007; $12: 815-33$

60. Gurunathan S, Jeong JK, Han JW, Zhang XF, Park JH, Kim JH. Multidimensional effects of biologically synthesized silver nanoparticles in Helicobacter pylori, Helicobacter felis, and human lung (L132) and lung carcinoma A549 cells. Nanoscale Res Lett 2015;10:1-17.

61. Govender R, Phulukdaree A, Gengan RM, Anand K, Chuturgoon AA. Silver nanoparticles of Albizia adianthifolia: The induction of apoptosis in human lung carcinoma cell line. J Nanobiotechnol 2013;11:5.

62. Xia T, Kovochich M, Liong M, Mädler L, Gilbert B, Shi H, et al. Comparison of the mechanism of toxicity of zinc oxide and cerium oxide nanoparticles based on dissolution and oxidative stress properties. ACS Nano 2008;2:2121-34.

63. Derfus AM, Chan WC, Bhatia SN. Intracellular delivery of quantum dots for live cell labeling and organelle tracking. Adv Mater 2004;16:961. 